\title{
High aluminium tolerance among ectomycorrhizal fungi
}

\author{
VEIKKO HINTIKKA
}

\begin{abstract}
Hintikka, V. 1988: High aluminium tolerance among ectomycorrhizal fungi. Karstenia 28:41-44.

The aluminium tolerances of 12 ectomycorrhizal and 48 saprophytic fungi, mainly basidiomycetes were studied by cultivating aseptic cultures on MMN or ME solution to which aluminium sulphate, potassium aluminium sulphate or aluminium chloride was added. Suillus luteus, S. variegatus, S. bovinus and Paxillus involutus grew in concentrations over $10 \mathrm{~g} \mathrm{Al}^{+++} / 1$. Species of Amanita and Tricholoma were more sensitive. Saprophytic species (Mycena, Marasmius, Pleurotus) had in general much lower tolerance, concentrations of $100-250 \mathrm{mg} \mathrm{Al}{ }^{++} / 1$ being limiting. It is suggested that the high tolerance of mycorrhizal species can be regarded as an adaptation to naturally aluminiumrich conditions in acid forest soils.
\end{abstract}

Veikko Hintikka, Dept. of General Botany, Univ. of Helsinki, Viikki, SF-00710 Helsinki, Finland

\section{Introduction}

The harmful effects of acidity and acid rains in forest soils are largely attributed to the toxicity of free aluminium $\left(\mathrm{Al}^{+++}\right)$ions. Thompson and Medve (1984) have indicated that several mycorrhizal fungi display a high tolerance of aluminium in aseptic culture, and growth occurs in concentrations of $500 \mathrm{ppm} \mathrm{Al}^{+++}$. In this paper, a similar and even higher tolerance of aluminium is reported among northern ectomycorrhizal fungi.

\section{Material and methods}

In the years 1984-1986 aseptic fungus cultures were isolated from fresh basidiocarps, collected in the vicinity of Helsinki, Finland, and kept on $1 \%$ malt extract (Difco) or MMN agar (Marx 1969) slants at ca. $+5^{\circ} \mathrm{C}$ with transfers about twice a year. In the experiments, aluminium sulphate, $\mathrm{Al}_{2}\left(\mathrm{SO}_{4}\right)_{3} \cdot 16 \mathrm{H}_{2} \mathrm{O}$, Baker anal. reag. 0010, aluminium potassium sulphate, $\mathrm{KAl}\left(\mathrm{SO}_{4}\right)_{2} \cdot 12 \mathrm{H}_{2} \mathrm{O}$, Merck pro analysi, art. 1047, or aluminium chloride, $\mathrm{AlCl}_{3} \cdot 6 \mathrm{H}_{2} \mathrm{O}$, Baker anal. reag. 002, was weighed into 100 or $250 \mathrm{ml}$ Erlenmeyer flasks. The flasks were closed with cotton plugs and sterilized dry at $130^{\circ} \mathrm{C}$ for $1 \mathrm{~h}$. Measured amounts of autoclaved hot MMN solution
(Marx 1969) were pipetted aseptically onto the aluminium salt, and the salt was allowed to dissolve. In high concentrations $\mathrm{KAl}\left(\mathrm{SO}_{4}\right)_{2}$ sometimes later crystallized. An inoculum piece of $\mathrm{MMN}$ or $\mathrm{ME}$ agar with fungus mycelium was placed floating on the surface of the liquid. Saprophytic species were grown similarly on $1 \%$ malt extract (Difco) solution. Radial growth was measured after 14-52 days. The aluminium sulphate medium was very acid; in a concentration of $1 \mathrm{~g} \mathrm{Al}^{+++} / \mathrm{l}$, the $\mathrm{pH}$ was 2.6 , in $5 \mathrm{~g} / \mathrm{l}$ it was 2.3 and in $10 \mathrm{~g} / \mathrm{l}$ it was 2.1-2.2. Small amounts of precipitate were seen, evidently due to the malt extract. Analysis of the filtrate of the culture medium with an atomic absorption spectrophotometer indicated that the aluminium was in solution and not precipitated.

\section{Results and discussion}

The mycorrhizal fungi proved to be very tolerant of aluminium in both the aluminium sulphate and potassium aluminium sulphate solutions. Fig. 1 shows the growth of some species in MMN solution to which aluminium sulphate was added. Mycelial growth of Suillus luteus (L.) Gray, S. variegatus (Sw.) D. Kuntze, S. bovinus (L.) O. Kunze and Paxillus invo- 


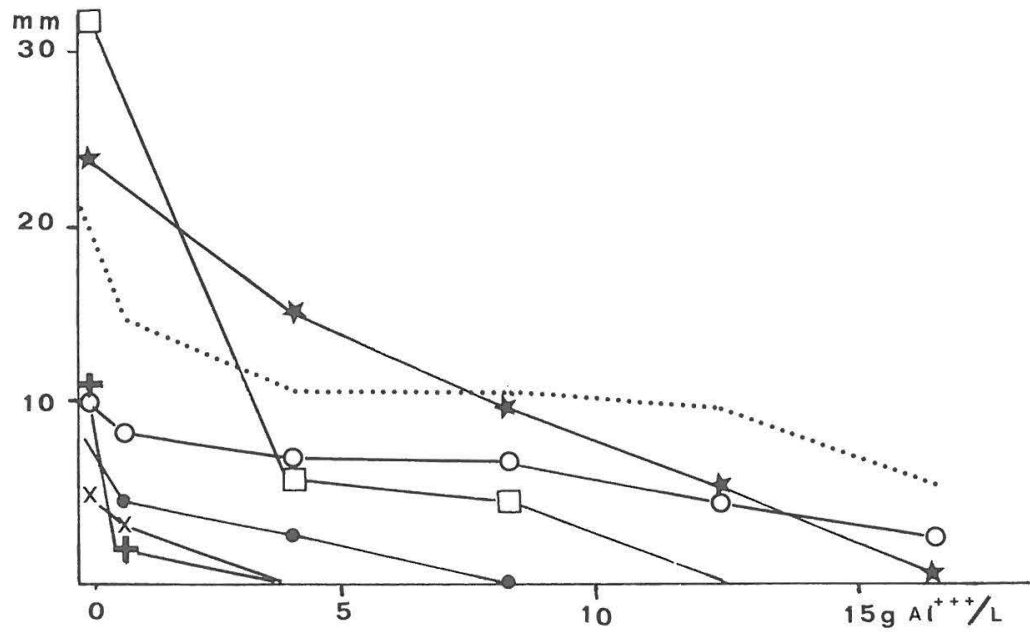

Fig. 1. Radial growth (vertical axis) of some ectomycorrhizal fungi in $\mathrm{MMN}$ solution to which $\mathrm{Al}_{2}\left(\mathrm{SO}_{4}\right) 3$. $16 \mathrm{H}_{2} \mathrm{O}=$ was added. ......... = Suillus variegatus, $0-0=S$. bovinus, *_* $=$ S. luteus, $\square-\square=$ Paxillus involutus, -. = Amanita muscaria, $\mathrm{x}-\mathrm{x}=$ Leccinum testaceoscabrum, and $++=$ Lactarius rufus. lutus (Batsch) Fr. occurred in solutions with an $\mathrm{Al}^{+++}$concentration of $15 \mathrm{~g} \mathrm{Al}^{+++} / \mathrm{l}$, and was fairly good in a concentration of $5 \mathrm{~g} \mathrm{Al}^{+++} / 1$. The latter solution contains about $100 \mathrm{~g} \mathrm{Al}_{2}\left(\mathrm{SO}_{4}\right)_{3} \cdot 16 \mathrm{H}_{2} \mathrm{O}$ per litre (10\%). Cenococcum geophilum Fr. formed new side colonies in this concentration. More sensitive fungi were Amanita muscaria (L.) Pers., A. rubescens Pers., Tricholoma albobrunneum (Pers.) Kumm., T. pessundatum (Fr.) Quél., Lactarius torminosus (Schaeff.) Pers., L. deterrimus Gröger and $L$. rufus (Scop.) Fr., their tolerances being $1-5 \mathrm{~g}$ $\mathrm{Al}^{+++} /$. On media containing potassium aluminium sulphate (Fig. 2) growth was approximately the same. Aluminium chloride proved to be more toxic, and growth was obtained for mycorrhizal species in concentrations of $0.5 \mathrm{~g} \mathrm{Al}^{+++} /$, some growth also occurring in a concentration of $1 \mathrm{~g} \mathrm{Al}^{+++} / \mathrm{l}$ in cultures of the tolerant species.
Compared with the mycorrhizal species, the saprophytic basidiomycetes were much more sensitive (Fig. 3). A few species (Pleurotus ostreatus) did not grow in concetrations of $10 \mathrm{mg} \mathrm{Al}^{+++} /$, and the maximum concentration for the majority of the 48 species tested was below $100 \mathrm{mg} \mathrm{Al}^{+++} / 1$.

In the following saprophytic species mycelial growth did not occur in a concentration of $100 \mathrm{mg}$ Al/l. The $\mathrm{pH}$ of this medium was 3.2-3.5.

\section{Agaricus abruptibulbus Peck}

Cerrena unicolor (Bull.) Murr.

Clavariadelphus ligula (Schoeff.) Donk

Coprinus atramentarius (Bull.) Fr.

Cudonia confusa Bres.

Flammulina velutipes (Curt.) Karst.

Fomes fomentarius (L.) Fr.

Fomitopsis pinicola (Sw.) Karst.

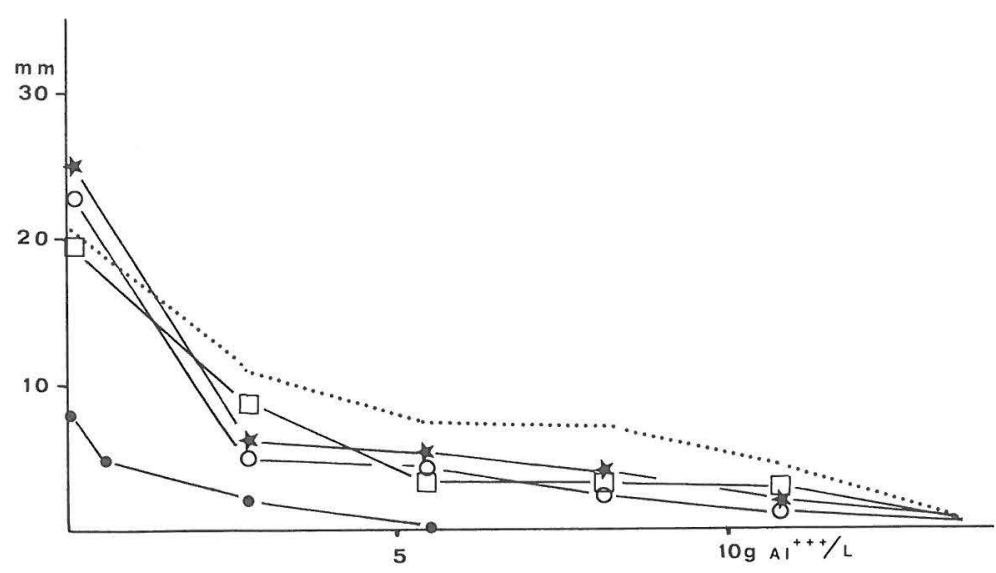

Fig. 2. Growth of some ectomycorrhizal fungi in $\mathrm{MMN}$ solution to which $\mathrm{KAISO}_{4} \cdot 12 \mathrm{H}_{2} \mathrm{O}$ was added. Symbols as in Fig. 1. 
Geopyxis carbonaria (Pers.) Sacc.

Hohenbuehelia serotina (Schrad.) Sing. Hypholoma capnoides (Fr.) Kumm.

H. fasciculare (Huds.) Kumm. Ischnoderma benzoinum (Wahlenb.) Karst.

Kuehneromyces mutabilis (Schaeff.)

Marasmius bulliardii Quél.

M. scorodonius (Fr.) Fr.

M. urens Fr.

Mycena aurantiomarginata (Fr.) Quél.

M. clavicularis (Fr.) Gill.

M. galopus (Pers.) Kumm.

$M$. iodiolens Lund.

M. laevigata (Lasch) Quél.

M. metata (Fr.) Kumm.

$M$. niveipes Murr.

M. sanguinolenta (Alb. \& Schw.) Kumm.

Phaeolepiota aurea (Matt.) Konr. \& Maubl.

Phellinus shrysoloma (Fr.) Donk

Phlebiopsis gigantea (Fr.) Jül.

Pholiota heteroclita (Fr.) Quél.

Piptoporus betulinus (Bull.) Karst.

Pleurotus pulmonarius (Fr.) Quél.

Pycnoporus cinnabarinus (Jacq.) Karst.

Stereum hirsutum (Willd.) Pers.

S. sanguinolentum (Alb. \& Schw.) Fr.

Tephrocybe tylicolor (Fr.) Moser

Trametes zonatella Ryv.

In the following saprophytic species the maximum concentration was $100-250(-500) \mathrm{mg} / \mathrm{l}$ :

Collybia asema (Fr.) Kumm.

C. dryophila (Bull.) Kumm.

Gymnopilus penetrans (Fr.) Murr.

Hapalopilus nidulans (Fr.) Karst.

Hygrophoropsis aurantiaca (Wulf.) Maire

Hypholoma sublateritium (Fr.) Quél.

Marasmius androsaceus (L.) Fr.

Micromphale perforans (Hoffm.) Gray

Mycena megaspora Kauffm.

Pholiota alnicola (Fr.) Sing.

Stropharia hornemannii (Fr.) Lund. \& Nannf.

Tephrocybe palustris (Peck) Donk

There is evidently a clear difference in aluminium tolerance between saprophytic and mycorrhizal basidiomycetes, the maximum concentrations being about $100 \mathrm{mg} / \mathrm{l}$ and $10 \mathrm{~g} \mathrm{Al}^{+++} / \mathrm{l}$, respectively. The difference might in certain cases be useful for separating mycorrhizal species from contaminating bacteria and fungal mycelia.

Comparison with the harmful concentrations of aluminium reported for other organisms shows that the saprophytic species tolerate about the same level as tree roots (Shier 1984, Simon \& Rothe 1985, Arovaara \& Ilvesniemi 1986, Göransson \& Eldhuset

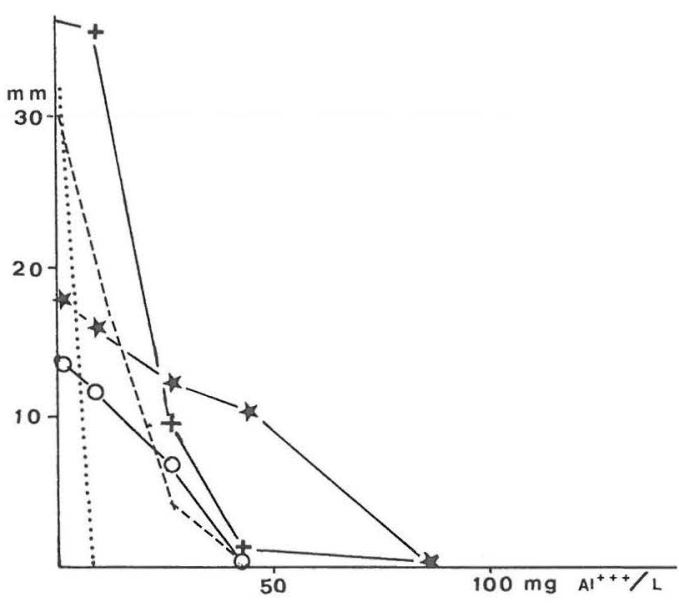

Fig. 3. Growth of some saprophytic basidiomycetes in ME solution to which aluminium sulphate was added. ......... = Pleurotus pulmonarius, $++=$ Cerrena unicolor, - . - - = Ischnoderma resinosa, $0-0=$ Marasmius urens, $\star-\star-\star \star \star=$ Mycena galopus.

1987) and some other fungi (Firestone et al. 1983, Orellana et al. 1985) and about the level reported to allow mycorrhizal formation (Entry et al. 1987). Entry et al. (1987) give higher values for Armillaria. The aluminium tolerance of ectomycorrhizal species seems to be exceptionally high, at least among eukaryotic organisms. However, in the present experiments a mould, Penicillium citrinum Thom. (determined at CBS, Baarn), grew in the same concentrations of aluminium as mycorrhizal species. In view of the above results, aluminium cannot be regarded as an efficient poison for mycorrhizal species.

The most tolerant mycorrhizal species (Suillus luteus, $S$. variegatus and $S$. bovinus) are characteristic of podzolic soils, the $\mathrm{pH}$ of which may be below 4 . Cenococcum is known to be a species of extreme habitats (Meyer 1987). In acid soils aluminium becomes soluble naturally. Although the aluminium concentrations reported for soil solutions of forest soils are considerably lower (0.4 mM, Ulrich 1980, $0.2 \mathrm{mM}$, Nilsson \& Bergkvist 1983), during dry periods the aluminium level may rise. Thus the high tolerance of mycorrhizal species may be interpreted as a natural adaptation to Al-rich conditions in highly acid soils.

Acknowedgements. This research was supported financially by a grant from the Finnish Ministry of Environment, the "HAPRO" project, and by a grant from the Academy of Finland. 


\section{References}

Bradley, R., Burt, A.J. \& Read, D.J. 1982: The biology of mycorrhiza in the Ericaceae VIII. The role of mycorrhizal infection in heavy metal resistance. - New Phytologist 91:197-209.

Entry, J.A. \& Cromack, K. Jr. 1987: Effect of pH, aluminium and sulphate on a high-elevation Armillaria isolate cultured in vitro. - Can. J. For. Res. 17:260-262.

Entry, J.A., Cromack, K. Jr., \& Stafford, S.G. 1987: The effect of $\mathrm{pH}$ and aluminium concentration on ectomycorrhizal formation in Abies balsamea. - Can. J. For. Res. 17:865-871.

Firestone, M.K., Killham, K. \& McColl, J.G. 1983: Fungal toxicity of mobilized soil aluminium and manganese. - Appl. Environmental Microbiol. 46:758761.

Göransson, A. \& Eldhuset, T.D. 1987: Effects of aluminium on growth and nutrient uptake of Betula pendula seedlings. - Physiol. Plantarum 69:193-199.

Marx, D.H. 1969: The influence of ectotrophic mycorrhizal fungi on the resistance of pine roots to pathogenic infection. I. Antagonism of mycorrhizal fungi to root pathogenic fungi and soil bacteria. - Phytopathology 59:153163.

Meyer, F.H. 1987: Extreme Standorte und Ektomykorrhiza (insbesonders Cenococcum geophilum). - Angew. Bot. $61,39-46$.

Nilsson, S.I. \& Bergkvist, B. 1983: Aluminium chemistry and acidification processes in a shallow podzol on the Swedish westcoast. - Water Air Soil Pollution 20:311329.

Orellana, R.G., Foy, C.D. \& Fleming, A.L. 1975: Effect of soluble aluminium on growth and pathogenicity of Verticillium albo-atrum and Whetzelina sclerotiorum from sunflower. - Phytopathology 65:202-205.

Schier, G.A. 1984: Response of red spruce and balsam fir seedlings to aluminium toxicity in nutrient solutions. Can. J. For. Res. 15, 29-33.

Simon, B. \& Rothe, G.M. 1985: Aluminium-bedingte Stoffwechsel-Änderungen in Fichtenkeimlingen. - Allgem. Forstzeitschr. 36:931-936.

Thompson, G.W. \& Medve, R.J. 1984: Effects of aluminium and manganese on the growth of ectomycorrhizal fungi. - Appl. and Environm. Microbiol. 48:556-560.

Ulrich, B. 1980: Die Wälder in Mitteleuropa: Messergebnisse ihrer Umweltbelastung, Theorie ihrer Gefährdung, Prognose ihrer Entwicklung. - Allgem. Forstz. 35:11981202.

Accepted for publication

on 10 June, 1988 